\title{
SPORY TERYTORIALNE PAŃSTW CZLONKOWSKICH NATO NA OBSZARZE ARKTYKI. UWARUNKOWANIA, ZNACZENIE ORAZ WPLYW GLOBALNEGO OCIEPLENIA
}

\begin{abstract}
Organizacja Paktu Północnoatlantyckiego (ang. North Atlantic Treaty Organisation, dalej: NATO) stanowi unikalny na skalę światową sojusz militarny, skupiający USA, Kanadę oraz znaczną część państw europejskich. Wyróżnia ją przede wszystkim przyjęta w ramach Karty Atlantyckiej zasada kolektywnej obrony przed zagrożeniami zewnętrznymi. Jednakże przynależność do tak silnej i istotnej organizacji militarnej nie gwarantuje współpracy pomiędzy jej członkami na płaszczyźnie politycznej. Przykładem są tutaj trudne relacje pomiędzy niektórymi państwami sojuszu w newralgicznym regionie Arktyki.

Podczas gdy uwaga świata skupiona jest w tym kontekście przede wszystkim na roszczeniu Federacji Rosyjskiej do Grzbietu Łomonosowa, a tym samym do bieguna północnego należy stwierdzić, że spory terytorialne mają miejsce także pomiędzy państwami NATO. W artykule przedstawione zostaną trzy z nich: spór pomiędzy Kanadą i Danią o skalistą wyspę Hans, pomiędzy Kanadą i USA dotyczący wytyczenia granicy morskiej na Morzu Beauforta oraz sprawa roszczenia Kanady do uznania Przejścia Północno-Zachodniego za jej wewnętrzne wody terytorialne, czemu w największym stopniu sprzeciwiają się Stany Zjednoczone, ale też i europejskie państwa członkowskie NATO.

Podłoże tych sporów w dużej mierze można sprowadzić do dwóch płaszczyzn: dostępu do surowców na obszarze Arktyki oraz możliwości ich transportowania, a także przepływu w okolicach Koła Podbiegunowego. W artykule przeanalizowane zostanie znaczenie tych sporów oraz obszarów, których dotyczą. Przedstawione zostaną także ich uwarunkowania oraz najważniejsze fakty dotyczące ich przebiegu. Zostanie także podjęta próba odpowiedzi na pytanie czy i w jaki sposób samo zaistnienie oraz pogłębianie się lub ograniczanie tempa rozwoju zjawiska globalnego ocieplenia może przez dalsze topnienie pokrywy lodowej wpłynąć na rozwój poddanych analizie spornych sytuacji.
\end{abstract}

\section{WYSPA HANS}

Wyspa Hans znajduje się w stanowiącym część Cieśniny Nares Kanale Kennedy’ego, pomiędzy należącą do Danii Grenlandią a kanadyjską Wyspą Ellesmere (patrz: Mapa 1). Cieśnina w najszerszym miejscu ma szerokość około 20 mil morskich (Hans). W ujęciu historycznym wyspa ta przez długi czas pozostawała nieznana dla Europej- 


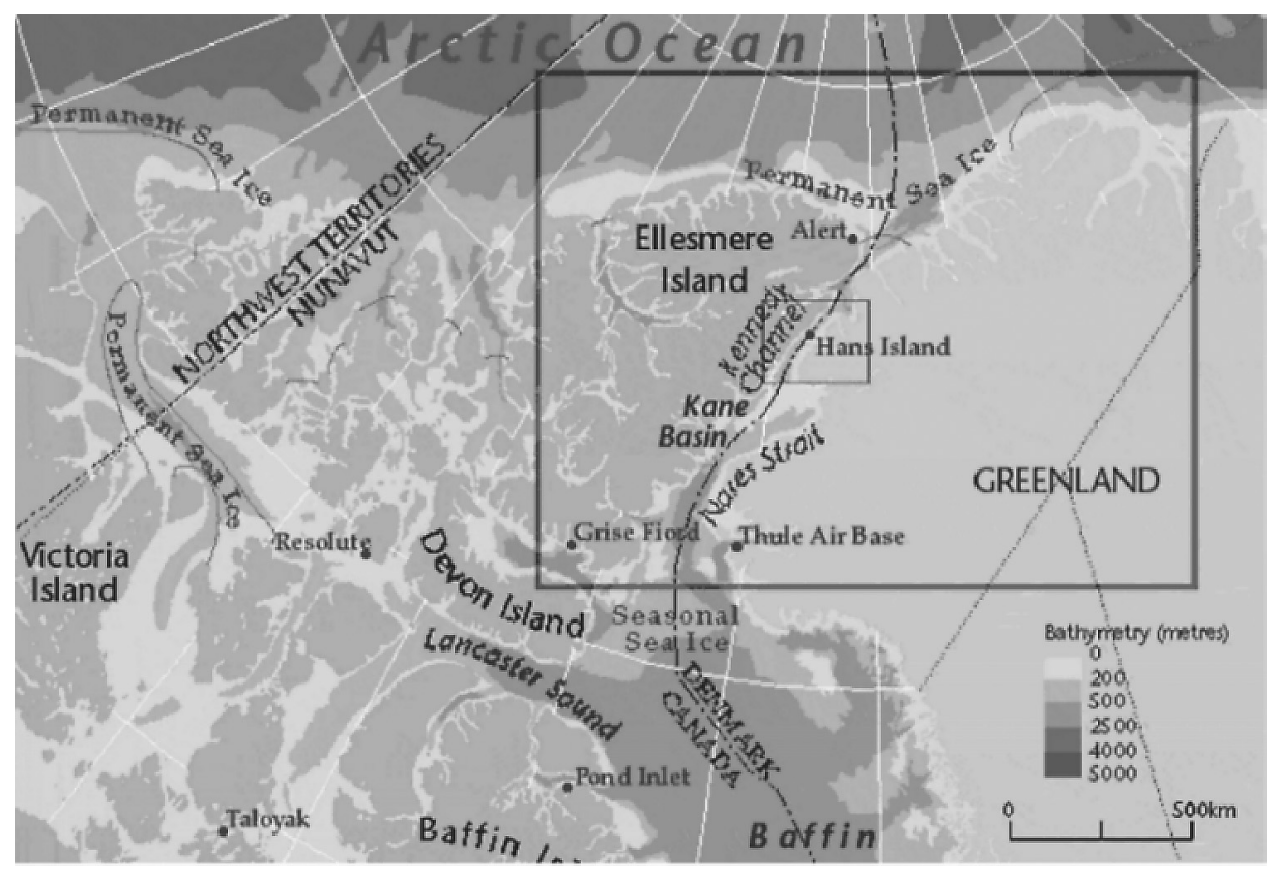

Mapa 1. Położenie Wyspy Hans

Źródło: Hans Island Maps, http://www.canadiangeographic.ca/hansIsland/maps.asp (5.08.2009).

czyków, dokonujących kolonizacji Ameryki Północnej. Dopiero w latach 1850-1880 na obszarze, na którym się znajduje miały miejsce pierwsze amerykańskie i brytyjskie ekspedycje (Guo, 2006: 134).

Status Hans przez lata pozostawał nieuregulowany. W roku 1933 Staty Trybunat Sprawiedliwości Międzynarodowej orzekł o przynależności Grenlandii do Danii, jednakże nie odniósł się do Wyspy Hans (ibidem: 134). Po raz pierwszy została ona wykorzystana - dla stworzenia bazy naukowej - przez Kanadę w krótkim okresie w trakcie II wojny światowej. Sama nazwa wyspy pojawiła się formalnie po raz pierwszy dopiero w roku 1950, kiedy przyjął ją kanadyjski Komitet Stały ds. Nazw Geograficznych (ang. Permanent Committee on Geographical Names) (Byers, 2013: 12). W roku 1971 w trakcie negocjacji z Danią po raz pierwszy władze Kanady stwierdziły, że wyspa należy do tego państwa (Kristensen; The Hans), jednakże w trakcie tych negocjacji nie przeprowadzono delimitacji na wyspie czy też dookoła niej, ustalenia takie miały miejsce w stosunku do szelfu kontynentalnego (ibidem). Samo roszczenie Kanady miało wtedy dwojakie podłoże: historyczne i geologiczne. Z jednej bowiem strony Kanada opierała swoje roszczenie na uwarunkowaniach historycznych, polegających na przejęciu od Wielkiej Brytanii w 1880 r. tzw. High Arctic Islands, z drugiej zaś w 1953 r. Eric Fry z Topographic Survey of Canada przeprowadzał badania na Wyspie, pozostawiając nawet w zbudowanym przez siebie kopcu notatkę o przynależności wyspy do Kanady. Rok później badania Erica Fry'a razem z dotyczącymi Grenlandii zostały powiązane z prowadzonymi przez rząd kanadyjski w ramach grupy badawczej, w której znajdowali się także duńscy badacze (Byers, 2013: 12). 
Granica morska biegnąca wzdłuż Cieśniny Nares została przez oba państwa uzgodniona $\mathrm{w}$ roku $1973 \mathrm{w}$ trakcie bilateralnych negocjacji i przebiegać miała w połowie cieśniny (Guo, 2006: 134). Przynależność Hans pozostawiono późniejszym ustaleniom (Canada). Według Michaela Byersa rok ten stanowi „datę krytyczną” w kontekście sporu o Wyspę Hans (Byers, 2013: 13), ponieważ oba państwa zaprezentowały wtedy jasno i wyraźnie swoje przeciwstawne wzajemnie pozycje. Od tego też momentu w celu zablokowania możliwości uzyskania praw do Wyspy oba państwa zaczęły stosować protesty dyplomatyczne.

W latach 1980-1983 usytuowana w Kanadzie korporacja DOME Petroleum prowadziła bez wiedzy Danii badania na wyspie. Według rządu Kanady również on nie posiadał o nich wiedzy (Denmark), podana jednak w cytowanym artykule informacja wydaje się być błędna, ponieważ według Michaela Byersa rząd Kanady wydał tej korporacji zezwolenie na utworzenie bazy badawczej w celu dokonania oceny wpływu przemieszczającej się pokrywy lodowej oraz gór lodowych na wybrzeża wyspy. Badania te miały służyć dokonaniu oceny wpływu tych czynników na platformy wiertnicze oraz na prowadzenie przybrzeżnych odwiertów (Byers, 2013: 13). Jak zwraca na to uwagę Rongxing Guo, lokalizacja Wyspy Hans jest dla tego celu ,perfekcyjna” (Guo, 2006: 135).

28 lipca 1984 r. minister ds. Grenlandii Danii Tom Høyern po przybyciu helikopterem na wyspę umieścił na niej duńską flagę, co spotkało się z protestami ze strony Kanady (Denmark; Byers, 2013: 13). Flagi Danii umieszczane były na Wyspie także w latach 1988, 1995, 2002, 2003 i 2004 (Byers, 2013: 13). Duńska flaga umieszczona została na wyspie przez załogę HDMS Tulugaq, duńskiej jednostki patrolowej, zaś następna przez duńską załogę stacjonującą w amerykańskiej bazie Thule. Z kolei w roku 2000 przy okazji badań nad północną częścią Ellesmere badania na wyspie prowadzili kanadyjscy geologowie (Denmark), w trakcie badań przeprowadzono mapowanie oraz pobrano próbki geologiczne (Byers, 2013: 13). Dwa lata później HDMS Veedderen dokonał wymiany duńskiej flagi z 1995 r. (ibidem: 14; Denmark), zaś kolejna wymiana dokonana została przez załogę HDMS Triton w roku 2003.

Należy przyznać, że przedstawicielom obu państw nie brakowało w kontekście prowadzonego sporu poczucia humoru, bowiem jak stwierdził to doradca ministra spraw zagranicznych Danii Peter Taksoe-Jensen: „Kiedy pojawia się tam duńskie wojsko, zostawia butelkę sznapsa. A kiedy przybywają tam siły zbrojne (Kanady), zostawiają butelkę Canadian Club (whisky) oraz napis głoszący «Witamy w Kanadzie»" (Byers, 2013: 13). W tamtym okresie nie brak było także bardziej zdecydowanych opinii, obecnych chociażby w mediach. Przykładowo przybycie statku Vcedderen na wyspę zostało w Kanadyjskiej gazecie „Globe and Mail” określone mianem przybycia duńskich „,najeżdżających hord" (ibidem: 14). De facto w Kanadzie uwagę opinii publicznej do kwestii Wyspy przyciągnął dopiero artykuł Roba Hueberta The Return of the Vikings, zamieszczony również w „Globe and Mail”.

W lipcu 2005 r. po raz pierwszy na wyspie pojawiła się flaga kanadyjska, umieszczona na niej przez żołnierzy tego państwa. Umieścili oni na wyspie tzw. Inukshuk, tradycyjną inuicką konstrukcję skalną wraz ze wspomnianą flagą (Guo, 2006: 135). W tym samym miesiącu podczas przeglądu stanowisk wojskowych (Iqaluit, Pond Inlet, Alert [Denmark...]) na wyspie pojawił się kanadyjski minister obrony Bill Graham 
(The Hans). Po odwiedzeniu tej mającej niespełna 1,3 $\mathrm{km}^{2}$ wyspy Graham stwierdził, że według Kanady jest ona jej częścią, a państwo to upewnia się, że Duńczycy będą zdawali sobie z tego sprawę (Canada; Denmark). Wnioskując po słowach Michaela Byersa, według którego mniejszościowy rząd kanadyjski pod przewodnictwem Paula Martina „chwiał się od jednego kryzysu do kolejnego” (Byers, 2013: 14), temat Wyspy Hans mógł być wtedy dla rządu Kanady tematem zastępczym na użytek komunikacji z opinią publiczną.

Dania zareagowała listem protestacyjnym (The Hans), nazywając takie działania okupacją (Denmark; Guo, 2006: 135), następnie ambasador Danii w Kanadzie Paul E. D. Kristensen zamieścił swój list w „Ottawa Citizen”. Stwierdził, że wyspa należy do Królestwa Danii. Dla potwierdzenia tego faktu w sierpniu na wyspe ponownie przypłynął HDMS Tulugaq (The Hans). Jednocześnie oba państwa postanowiły wznowić negocjacje, zaś w przypadku ich niepowodzenia sprawa miała zostać oddana pod rozpatrzenie przez Międzynarodowy Trybunał Sprawiedliwości (Guo, 2006: 135). W kontekście tych rozmów (8 sierpnia) wystosowana jednocześnie została przez władze Danii zapowiedź (15 sierpnia), że wspomniany statek nie odwiedzi ponownie wyspy w 2005 r. O zgodzie władz Kanady na wspomniane rozmowy powiadomił ówczesny premier Danii i późniejszy Sekretarz Generalny NATO Anders Fogh Rasmussen. Ministrowie spraw zagranicznych obu państw mieli spotkać się podczas posiedzenia Zgromadzenia Ogólnego ONZ, przy okazji 60. rocznicy istnienia Organizacji. Podczas rozmów minister spraw zagranicznych Kanady ogłosił, że zostało osiagnięte porozumienie co do procesu mającego na celu rozwiązanie sporu (The Hans). W rzeczywistości jednak osiagnięte porozumienie przypominało rozwiązanie z roku 1973: zadeklarowano jedynie podjęcie prac nad osiągnięciem porozumienia co do przynależności Hans. Ustalenia z lat 70. XX wieku zostały przywołane w treści wspólnego oświadczenia ${ }^{1}$.

Po roku 2005 wydawało się, iż spór w perspektywie mógłby zostać zażegnany, jednakże kolejne wydarzenia sprawiły, że jego rozwiązanie wydaje się wciąż być odległe. O ile od 1967 r. Kanada umieszczała na swoich mapach Wyspę Hans całkowicie w ramach swoich wód terytorialnych, o tyle zdjęcia satelitarne z roku 2007 doprowadziły do umieszczenia jej dokładnie w połowie Kanału Kennedy’ego (Satellite). Być może fakt ten miał wpływ na deklarację premiera Grenlandii z 2008 r., w której wyraził on przekonanie, że Wyspa Hans pierwotnie należała do mieszkańców Grenlandii (Boswell, Hans). Należy także pamiętać o tym, iż w latach 2007 i 2008 arktyczna pokrywa lodowa w okresie letnim była znacznie mniejsza niż w latach poprzednich, co z pewnością nie pozostawało bez wpływu na opinie i pozycje rządów. W roku 2012 pojawiły się sygnały o możliwym porozumieniu w sprawie wyspy (Mackrael, Canada). W sieprniu 2013 r. pojawiła się nawet informacja o wycofaniu się Kanady z działalności militarnej w odniesieniu do Wyspy. Jednocześnie za prawdopodobny zaczęto uważać scenariusz równego podziału Wyspy pomiędzy oba zainteresowane państwa, co w swojej książce sugerował także Michael Byers (Byers, 2013: 15).

1 Pełna treść wspólnego stanowiska: Joint Statement, http://w01.international.gc.ca/minpub/Publication. asp $x$ ?isRedirect $=$ True $\&$ publication_id=383048\&Language $=\mathrm{E}(5.08 .2009)$. 
W kontekście artykułu istotne jest określenie powiązania sporu o Wyspę Hans ze zjawiskiem globalnego ocieplenia oraz z możliwościami obu państw do sprawowania nad nią kontroli. Należy podkreślić, że świat nauki był (i w dużej mierze nadal pozostaje) zszokowany tempem topnienia arktycznej pokrywy lodowej (DeMille, Denmark), zaś Kanada i Dania były tego świadome. Dowód na to widoczny jest w tekście wspólnego stanowiska z września 2005 r., wspomina się w nim o istniejącej już współpracy obu państw w kwestiach związanych ze zmianami klimatycznymi, wydobyciem surowców oraz transportem (Joint). Można odnaleźć sugestie, zgodnie z którymi Kanada stawała się w coraz większym stopniu asertywna w kwestii swoich roszczeń terytorialnych w Arktyce z powodu potencjalnego wpływu globalnego ocieplenia na wydobycie oraz transport (Denmark). Potwierdzenie tego wpływu jest obecne w opisie omawianego sporu na stronie „Foreign Policy”, zgodnie z nim niedostępne dotąd trasy morskie otwierają się dla możliwości przepływu, przy czym zagadnienie to wiązane jest także z Przejściem Północno-Zachodnim (The List; Huebert, 2002).

Dążenie do wejścia w posiadanie Wyspy Hans wiązane jest także z dostępem do bogatych w ryby (skarpie) oraz krewetki (Huebert, 2002) ${ }^{2}$ terenów morskich (Bronskill, Hans; Satellite). Istnieją jednak opinie, że roszczenia Kanady mają większy związek z Przejściem niż z samą Wyspą Hans (Harper). Wydają się one uzasadnione w kontekście porozumienia z lat 70 . XX wieku. O ile Greenpeace sugeruje, że spór może mieć związek z uzyskaniem dodatkowej granicy morskiej (zgodnie z prawem morza: do 12 mil morskich, co przy szerokości Cieśniny Nares - 20 mil morskich - miałoby zasadnicze znaczenie), o tyle w kontekście wspomnianego porozumienia sugestia ta jest bezpodstawna, ponieważ wytyczając granicę morską w Cieśninie Kanada i Dania poprowadziły linię graniczną do południowego krańca wyspy przerywając ją, a następnie kontynuując od jej północnego krańca (Satellite), zatem zgodnie z tym ustaleniem wyspa nie posiada wód terytorialnych (Harper). Nieco inne informacje przytacza w tym kontekście Michael Byers, według którego pozostawiono zarówno na północ, jak i na południe od wyspy przestrzeń o długości 875 metrów (Byers, 2013: 14), nie ma to jednak w dalszym ciagu wpływu na przebieg granicy morskiej. Oba państwa są zresztą tego świadome, co znalazło potwierdzenie we wspólnej deklaracji z września 2005 r., w której stwierdzono: ,podkreślamy, że to zagadnienie [sporu terytorialnego, przyp. aut.] odnosi się tylko do wyspy jako takiej i nie ma żadnego wpływu na porozumienie" (z 1973 r.) (Byers, 2013: 14).

W kontekście powyższych informacji dążenie któregokolwiek z państw do uzyskania nowych wód dla połowu ryb, eksploatacji złóż czy też kontroli potencjalnego przepływu statków wiązałoby się z zerwaniem tegoż porozumienia, nie można jednak tego całkowicie wykluczyć. O ile bowiem obecnie Cieśnina przez większość roku pokryta jest lodem, o tyle w przypadku zmiany tego stanu rzeczy posiadanie Wyspy Hans stałoby się pretekstem dla prowadzenia kontroli przepływających jednostek.

W kontekście sporów terytorialnych oprócz powodów istotna jest realna możliwość kontrolowania danego terytorium, sama argumentacja stron wydaje się być jedynie narzędziem. Kanada posiada w tym regionie regiment Rangersów, zaś w roku 2005

2 Pojawiały się także informacje o prowadzonych przez mieszkańców Grenlandii nielegalnych polowaniach na niedźwiedzie polarne. 
w ćwiczeniach brało udział 360 marynarzy i żołnierzy kanadyjskich (Denmark), a Cieśninę Davisa patrolowała fregata HMCS Frederiction, badając m.in. sprawę nielegalnych połowów prowadzonych przez statki ze znajdujących się pod protektoratem Danii Wysp Faroe (Wallace). Pojawiają się jednak sugestie, że to Dania posiada zdolności wojskowe dla poparcia swoich roszczeń (DeMille), przykładem może być stacjonowanie w okolicach Hans duńskiej marynarki wojennej (Huebert, 2002). O ile kanadyjska straż przybrzeżna jest niezwykle profesjonalną i jedną z najlepiej wyszkolonych na świecie, to jej niewielka liczebność, wysłużony sprzęt oraz znaczne niedofinansowanie (ibidem) stawia pod znakiem zapytania jej skuteczność. Jak podaje Rob Huebert, cytowany już wcześniej kanadyjski politolog z Centre for Military and Strategic Studies Uniwersytetu Calgary, w przeciwieństwie do jednostek duńskich brak jest odpowiednio wzmocnionych jednostek kanadyjskich, jedynie straż przybrzeżna posiada pięć lodołamaczy zdolnych dotrzeć w okolice Wyspy Hans (ibidem). Sprawa Wyspy Hans jest zresztą okazjonalnie wykorzystywana przez marynarkę wojenną Kanady do podniesienia problemu potrzeby inwestycji i wyposażenia marynarki we wzmocnione pod względem odporności na lód okręty wojenne (Guo, 2006: 135). Według Hueberta świadczy to o niemalże całkowitej niemożności Kanady do obrony jej interesów na północy (Huebert, 2002), zagadnienie to zostanie przywołane ponownie w dalszej części artykułu.

\section{MORZE BEAUFORTA}

Podobnie jak sprawa Wyspy Hans, amerykańsko-kanadyjski spór o część Morza Beauforta ma związek ze zjawiskiem globalnego ocieplenia, przy czym w tym przypadku jako czynnik warunkujący przebieg sporu ma ono większe znaczenie. Omawiana sporna sytuacja ma swoje korzenie jeszcze w XIX wieku i dotyczy podpisanego jeszcze w 1825 r. traktatu granicznego, przy czym sygnatariuszami były Rosja oraz Wielka Brytania. W późniejszym okresie tego wieku, po zakupie Alaski w 1867 r., nastąpiło przejęcie praw Rosji przez Stany Zjednoczone oraz przejęcie praw Wielkiej Brytanii przez Kanadę w 1880 r. W traktacie określono granicę Alaski jako linię biegnącą wzdłuż 141 południka (Baker, Byers 2012: 71-72).

Według Kanady również granica morska pomiędzy tym państwem oraz Stanami Zjednoczonymi powinna przebiegać tak, jak granica między Yukonem i Alaską: zgodnie ze 141 południkiem w analogiczny sposób, w jaki została wytyczona granica morska pomiędzy ZSRR a Stanami Zjednoczonymi ${ }^{3}$. Takie stanowisko Kanady można także częściowo wiązać z forsowaną przez to państwo do momentu przyjęcia Konwencji o prawie morza tzw. teorią sektorów arktycznych. Ma ona swoje korzenie w ogłoszonym przez Kanadę w 1925 r. postulatem co do rozszerzenia granic w kierunku Bieguna Północnego przez wyznaczenie opartego na wybrzeżu trójkąta ulokowanego pomiędzy 60 a właśnie 141 południkiem, analogiczne roszczenie wysunął zresztą także ZSRR. Teoria sektorów bazowała na zasadzie „,przylegania i ciagłości”, która miała zapobiec sytuacji, w której w przypadku braku efektywnej okupacji poszczególnych

3 Na podstawie: F. Côté, R. Dufresne, The Arctic: Canada's legal claims, „Inforeries”, 24.10.2008, s. 4; Beaufort Sea, http://www.absoluteastronomy.com/topics/Beaufort_Sea (6.08.2009). 
wysp i archipelagów przez państwa wysuwające roszczenia do sektorów mogłyby zostać uznane przez inne państwa, w tym sąsiednie za terra nullis.

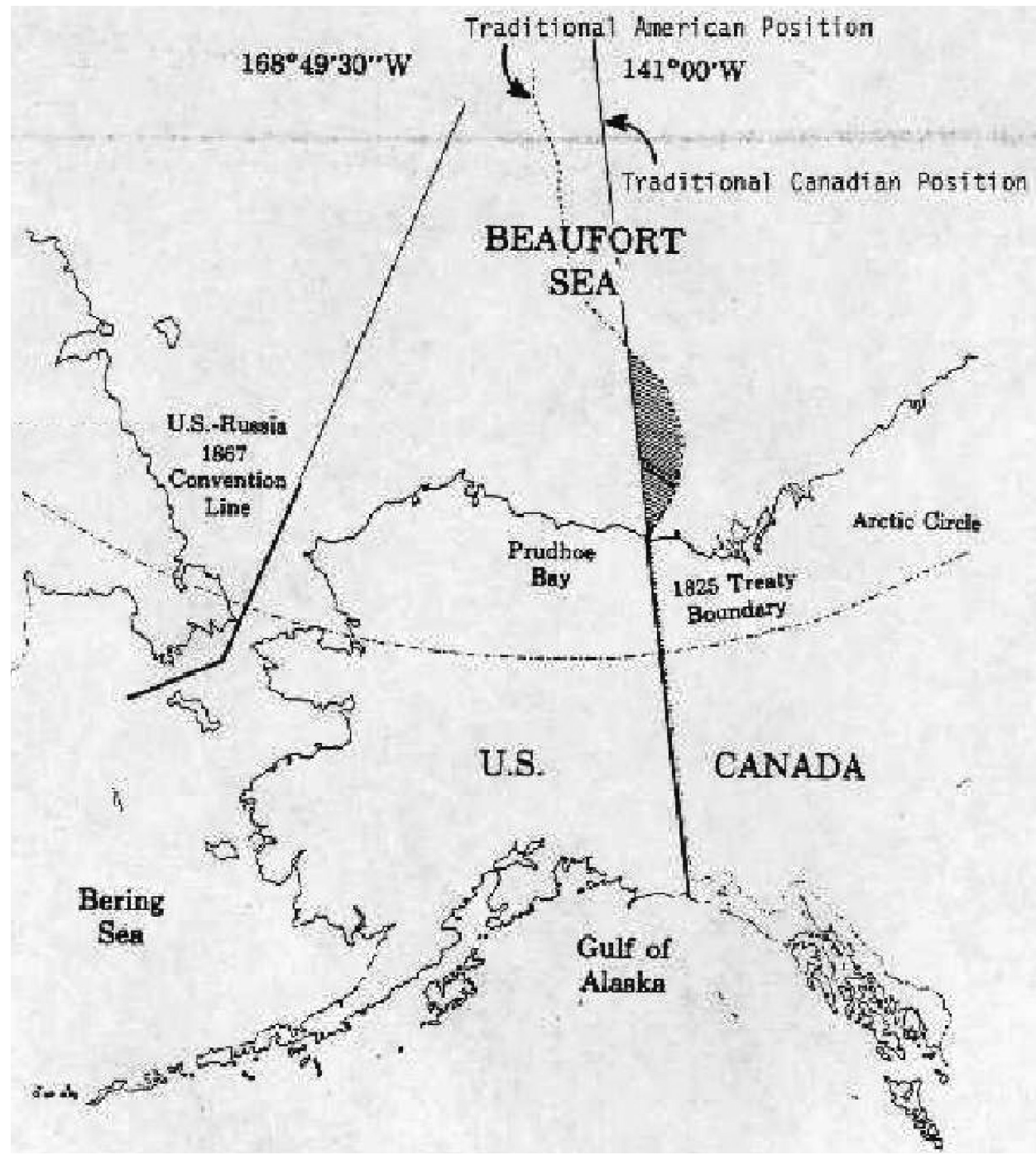

Mapa 3. Poglądy Stanów Zjednoczonych i Kanady na przebieg granicy morskiej na Morzu Beauforta, jego część sporna oraz porównanie do granicy morskiej Rosja-Stany Zjednoczone Źródlo: E. LeGresley, The Law of Sea Convention, http://dsp-psd.pwgsc.gc.ca/Collection-R/LoPBdP/ BP/bp322-e.htm (6.08.2009).

Sama teoria spotkała się jednak ze zdecydowanym odrzuceniem nie tylko przez inne państwa arktyczne, ale także generalnie przez społeczność międzynarodową (Symonides, 2008: 33-34). Teorię tę odrzucały także Stany Zjednoczone, których zdaniem omawiana granica na Morzu Beauforta powinna zostać wytyczona za pomocą metody równych odległości poprzez wyznaczenie prostopadłych do siebie linii o długości do 
200 mil morskich, stanowiących potencjalną wyłączną strefę ekonomiczną (ang. Exclusive Economic Zone - EEZ), mających swój początek w najbliższym punkcie wybrzeży obu państw; na ich skrzyżowaniu w efekcie powstaną punkty, które połączone dadzą ostateczną proponowaną przez Stany Zjednoczone granicę morską (patrz: Mapa 3).

Zastosowanie rozwiązania proponowanego przez Stany Zjednoczone miałoby według Jamesa S. Bakera i Michaela Byersa dodatkowy skutek dotyczący przebiegu wyłącznej strefy ekonomicznej na północ od wytyczonej granicy morskiej. Sytuacja ta ma miejsce przede wszystkim z powodu usytuowanej na wschód od spornego obszaru kanadyjskiej Wyspy Banksa, co powoduje, że przy zastosowaniu proponowanej przez USA metody powstała linia najpierw zbliża się do 141 południka, a następnie skręca jeszcze dalej na zachód (patrz: mapa 4). Jak dotąd jednak zarówno Kanada, jak i USA

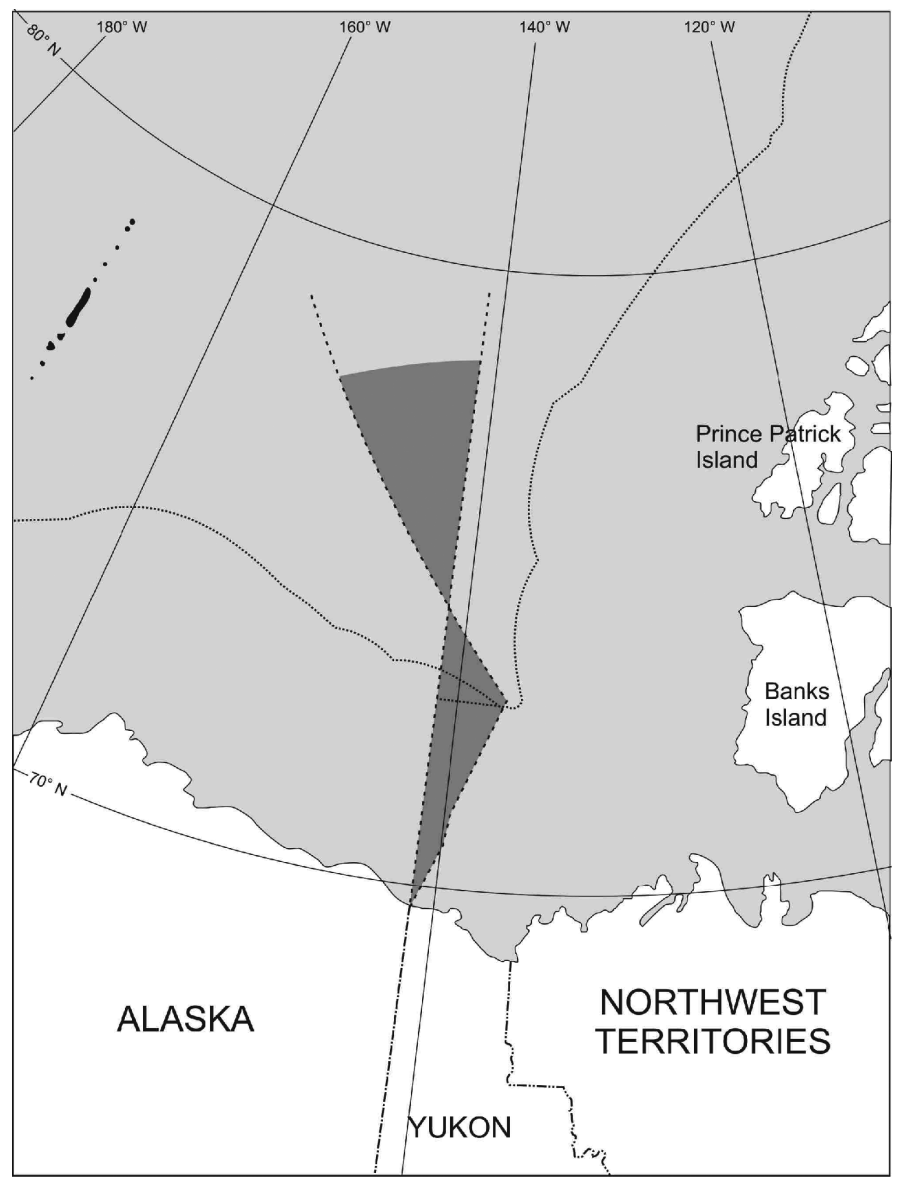

Mapa 4. Przebieg spornej granicy według proponowanych przez USA i Kanadę rozwiązań z uwzględnieniem obszaru poza wyłączną strefą ekonomiczną

Źródło: C. Schofield, I. Townsend-Gault, Of Parallels and Meridians: Implications of Barents Sea Dispute Resolution for the Beaufort Sea, http://www.zeitschrift.co.uk/indexv7n1.html (28.02.2014).

${ }^{4}$ Na podstawie: F. Côté, R. Dufresne, The Arctic, op. cit., s. 4; Beaufort Sea..., op. cit. 
nie odniosły się do kwestii przebiegu tej linii poza spornym obszarem na Morzu Beauforta (Baker, Byers, 2012: 72).

Kontynuując te rozważania należy podkreślić, że w przypadku potencjalnego stwierdzenia, że szelf kontynentalny pod Morzem Beauforta ulega przedłużeniu w kierunku bieguna, zaś stanowisko Kanady faworyzowałoby Stany Zjednoczone i odwrotnie, co według Jamesa S. Bakera i Michaela Byersa stworzyłoby możliwość zamiany dotychczasowej gry o sumie zerowej na swoisty handel wymienny (ibidem: 74). Autorzy przewidują także interesująca możliwość zachowania się tych dwóch państw w przypadku rozszerzenia ich stanowisk poza EEZ. W takiej sytuacji rozwiązanie mogłoby okazać się proste i polegałoby na unilateralnym uznaniu stanowiska drugiej strony przez jedno z państw, automatycznie zamykając mu dalsze możliwości w kwestii roszczeń. Dla wykonania takiego kroku niezbędne jednak byłoby jednoznaczne stwierdzenie, że potencjalne straty związane z przyjęciem niekorzystnego rozwiązania w odniesieniu do Morza Beauforta byłyby mniejsze niż zyski wynikające z rozszerzenia roszczenia poza wyłączną strefę ekonomiczną (ibidem: 78).

Omawiany obszar sporny ma powierzchnię $6250 \mathrm{~km}^{2}$ (Boswell, Arctic), zaś podłożem sporu są złoża surowców energetycznych takich jak ropa naftowa i gaz ziemny. Stany Zjednoczone zainteresowane są przede wszystkim złożami znajdującymi się w okolicach Prudhoe Bay, jest to największe znane amerykańskie złoże ropy naftowej położone na zachodzie terenu spornego. Wydobycie z tego złoża stanowi około $25 \%$ ogólnej produkcji ropy naftowej w USA. Natomiast w polu zainteresowań Kanady znajduje się pole Amauligak znajdujące się w kanadyjskiej części Morza Beauforta (Fogarassy: 3-4). Na terenie spornym również powinno zatem znajdować się niezwykle bogate złoże. Zdaniem Randy'ego Boswella z Canwest News Service teren ten znajduje się w centrum pola uważanego za jedno $\mathrm{z}$ najlepszych ze znajdujących się na terenach polarnych złóż (Boswell, Arctic).

Powyższe informacje znalazły swoje potwierdzenie w przeprowadzonych na Morzu Beauforta przez korporacje petrochemiczne badaniach. W roku 2006 korporacja Devon Canada stwierdziła, że na północ od kanadyjskich Terytoriów Północno-Zachodnich znajdować się może 250 milionów baryłek ropy. W kolejnych dwóch latach Imperial Oil, Exxon Mobil Canada (w 2007 r.) oraz British Petroleum (w 2008 r.) wydały odpowiednio 585 milionów dolarów kanadyjskich oraz 1,2 miliarda dolarów kanadyjskich dla uzyskania praw do eksploracji złóż na sąsiadujących ze sobą obszarach, zaś w 2010 r. porozumiały się nawet w tej sprawie. Z kolei na obszarze Morza Beauforta należącego do USA podobne inwestycje za „miliardy dolarów” poczynił Shell. Jak oceniają to James S. Baker oraz Michael Byers problemem nie jest obecność ropy i gazu ziemnego pod Morzem Beauforta, ale ceny rynkowe, które sprawiłyby, że ich wydobycie stałoby się opłacalne, sposób dostarczenia tych surowców na rynek, standardy bezpieczeństwa oraz sposób, w jaki Stany Zjednoczone i Kanada rozwiążą trwający spór (Baker, Byers, 2012: 71).

Pomimo sporu oba państwa prowadziły na terenie Morza Beauforta wspólne badania naukowe, mające na celu zbadanie powierzchni dna morskiego. Jednakże należy przy tym zaznaczyć, że ekipy biorące udział w badaniach nie zbierały danych z obszaru sporego, jak thumaczy to Jacob Verhoef kierujący badaniami z ramienia Kanady nie były zbierane dane na terenie kanadyjskiej i amerykańskiej strefy ekonomicznej (We- 
ber). Świadczy to o ostrożności w podejściu badaczy do tego terenu. Podobną postawą charakteryzują się potencjalni inwestorzy: chociaż zarówno Kanada, jak i Stany Zjednoczone wystawiły na sprzedaż prawa do eksploatacji złóż, żadna korporacja nie wystapiła o ich zakup (ibidem). W 2012 r. premier Kanady Stephen Harper miał poprowadzić aukcję praw do wydobycia, jednakże żadna ze znaczących korporacji nie wzięła w niej udziału. De facto jedynie małe brytyjskie przedsiębiorstwo zakupiło wtedy prawa do $9 \mathrm{~km}^{2}$ za około 7,5 miliona USD (Byers, Stephen). Sam fakt wystawienia tych praw na sprzedaż wydaje się być sprzeczny, a jednocześnie pokazywać ewolucję podejścia tych państw w odniesieniu do przytaczanej przez Jamesa S. Bakera i Michaela Byersa informacji o istniejącym de facto moratorium na wydobycie na spornym obszarze (Baker, Byers, 2012: 73).

Sam spór właśnie w kontekście surowców zaistniał zresztą dopiero w latach 70 . W latach 60. XX wieku władze Kanady wydały zezwolenia na poszukiwania ropy i gazu na spornym obszarze, co nie spowodowało żadnego protestu ze strony Stanów Zjednoczonych. Protest taki pojawił się dopiero w roku 1970, w którym Kanada ujęła ten obszar w swoim Arctic Waters Pollution Prevention Act, jednakże nie odnosił się do zastosowania linii 141 południka. W tym znaczeniu protest USA pojawił się dopiero w roku 1976, w którym kanadyjskie władze wydały więcej zezwoleń, co spowodowało z kolei ustanowienie przez Kanadę strefy połowu ryb przy wykorzystaniu 141 południka, na co władze USA zareagowały ustanowieniem własnej strefy przy zastosowaniu metody równych odległości (Baker, Byers, 2012: 75). Sprawa rybołówstwa - podobnie jak w przypadku Wyspy Hans - stała się zresztą drugim po kwestii surowców podłożem omawianego sporu. W 2009 r. Stany Zjednoczone wprowadziły restrykcje dotyczące połowu ryb w Arktyce, uzasadniając to zwiększającym się zainteresowaniem połowami spowodowanym topnieniem pokrywy lodowej w efekcie pogłębiania się globalnego ocieplenia (Secretary), proponując jednocześnie wprowadzenie zakazu połowów na spornym obszarze Morza Beauforta (US to ban), na co Kanada zareagowała protestem (Boswell, 2009).

Pod koniec lat 70. XX wieku oba państwa zamierzały rozwiązać sprawę Morza Beauforta wraz z innymi spornymi kwestiami, w tym przede wszystkim sprawą Zatoki Maine. Kanada była nawet skłonna ponieść pewne „straty” na Morzu Beauforta przy jednoczesnych zyskach w innych miejscach, przy czym można tu domniemywać, że chodziło głównie o sprawę głośnego w tamtym czasie sporu dotyczącego Zatoki Maine. Jednocześnie żadna ze stron nie chciała zgodzić się na jakikolwiek kompromis w kwestii swojego stanowiska i jego prawnego uzasadnienia $\mathrm{z}$ obawy przed poniesieniem strat w przypadku innych delimitacji. Ostatecznie to sprawa Zatoki jako ważniejsza stała się w pierwszej kolejności przedmiotem negocjacji (Baker, Byers, 2012: 73). Pierwotnie m.in. negocjatorzy uzgodnili możliwość korzystania ze spornych wód przez rybaków obu państw, jednakże zaproponowany traktat napotkał opór ze strony Senatu Stanów Zjednoczonych (Baker, Byers, The Beaufort Sea: 2). Sprawa ta następnie została oddana pod decyzję Międzynarodowego Trybunału Sprawiedliwości, a spór na Morzu Beauforta stał się ponownie oddzielną - i wciąż nierozwiązaną, chociaż „,dobrze zarządzaną" - kwestią (Baker, Byers, 2012: 73).

Pojawić się może pytanie dlaczego oba państwa nie skierowały do Trybunału również sprawy sporu na Morzu Beauforta? Powodem mogło być tutaj szerokie niezado- 
wolenie z wyroku w sprawie Zatoki Maine. Pierwsza krytyczna opinia dotycząca tego wyroku pochodziła od jednego z sędziów składu orzekającego, André Grosa z Francji, zdaniem którego dokonano po prostu „równego podziału”, który według większości wynikał wyłącznie z uznania dokonanego przez trybunał (Collins, Jr, Rogoff, 1986: 6-7). Co interesujące i warte podkreślenia, według André Grosa granica w Zatoce Maine powinna była przebiegać zgodnie z zasadą równych odległości (ibidem: 1) w sposób podobny do tego, jaki postulują Stany Zjednoczone w odniesieniu do granicy na Morzu Beauforta. Inni krytycy podnosili fakt, że orzekając w sprawie Zatoki Maine Międzynarodowy Trybunał Sprawiedliwości skoncentrował się na czynnikach geograficznych, pomijając rozmieszczenie zasobów na spornym obszarze oraz możliwości zarządzania nimi, według jednej z opinii spór nie dotyczył geografii, ale był skoncentrowany na kwestii przydziału praw do wykorzystania zasobów morskich, zaś decyzja trybunału nie odzwierciedlała wagi tej płaszczyzny sporu (ibidem: 7). W kontekście sporu na Morzu Beauforta obecne na spornym obszarze zasoby mają jeszcze większe znaczenie, a zatem obawa zarówno Kanady, jak i Stanów Zjednoczonych co do potencjalnej decyzji Trybunału jest uzasadniona. Dodatkowym argumentem jest tutaj fakt, który w swoim artykule podnoszą Edward Collins Jr. oraz Martin A. Rogoff, otóż orzeczenie w sprawie Zatoki Maine było pierwszym obejmującym delimitację granicy morskiej w odniesieniu zarówno do szelfu kontynentalnego, jak i przykrywających go wód, a według cytowanych autorów prawo dotyczące delimitacji granic morskich rozwija się przede wszystkim w oparciu o orzecznictwo międzynarodowe (ibidem: 7-8). Wnioskując: orzeczenie w sprawie Zatoki Maine mogłoby mieć wpływ na orzeczenie w sprawie sporu na Morzu Beauforta.

Przez zdecydowaną większość roku Morze Beauforta jest zamarznięte, jednakże zdaniem Roba Hueberta globalne ocieplenie stworzyło obecnie warunki konfliktogenne dla relacji kanadyjsko-amerykańskich. W podobnym tonie na konferencji zorganizowanej przez Canada Institute, na której obaj byli obecni, wypowiadał się też Michael Byers, który zwracał uwagę na fakt, że między wrześniem 2006 i 2007 r. stopiło się około 1,2 miliona $\mathrm{km}^{2}$ arktycznego lodu. Ten stan rzeczy zdaniem R. Hueberta doprowadzić może do „znaczącego konfliktu” między Stanami Zjednoczonymi a Kanadą o kontrolę nad sporną częścią Morza Beauforta, może on być nawet poważniejszy niż sprawa przejścia, a w przyszłości może dojść do eskalacji sporu.

Jednocześnie zwrócił także uwagę na fakt, że aby skutecznie móc ubiegać się o sporny teren Stany Zjednoczone musiałyby ratyfikować Konwencję Narodów Zjednoczonych o prawie morza. Niejako odpowiadając na sugestie Hueberta jeszcze administracja George'a W. Busha w 2007 r. podjęła działania na rzecz ratyfikacji konwencji. Według Toma Casey'a z ówczesnego Departamentu Stanu przyjęcie konwencji jest jedynym sposobem dla zabezpieczenia amerykańskich interesów związanych z oceanami. W tym samym okresie Stephen Harper, premier Kanady, zapowiedział serię naukowych i infrastrukturalnych projektów dla obrony kanadyjskiej suwerenności na północy (Canada and). Jednakże ani George W. Bush, ani jego następca Barack Obama jak dotąd nie ratyfikowali konwencji. Jak wskazują na to powyższe fakty, spór ten jest znacznie istotniejszy niż w przypadku Wyspy Hans i należy się spodziewać, że globalne ocieplenie w przypadku dalszego postępowania tego zjawiska spowoduje dalsze pogłębianie się sporu. 


\section{SPRAWA PRZEJŚCIA PÓŁNOCNO-ZACHODNIEGO}

Przejście Północno-Zachodnie to trasa morska biegnąca od Cieśniny Davisa między kanadyjskimi wyspami do Zatoki Baffina. Składa się ono z siedmiu możliwych tras, z których dwie uznawane są za główne (Côté, Dufresne: 3). Waga tego przejścia jest o tyle duża, że jak pokazuje to poniższa mapa mogłoby ono być niezwykle ekonomiczną alternatywą dla drogi morskiej prowadzącej przez Kanał Panamski. Licząc w milach morskich, droga przez Przejście jest o około 2150 mil krótsza (Canada flexes), inne źródła podają porównanie drogi z Europy do Azji jako 7900 mil wobec 12600 mil (Dube, 2006).

\section{口 NORTHWEST PASSAGE}

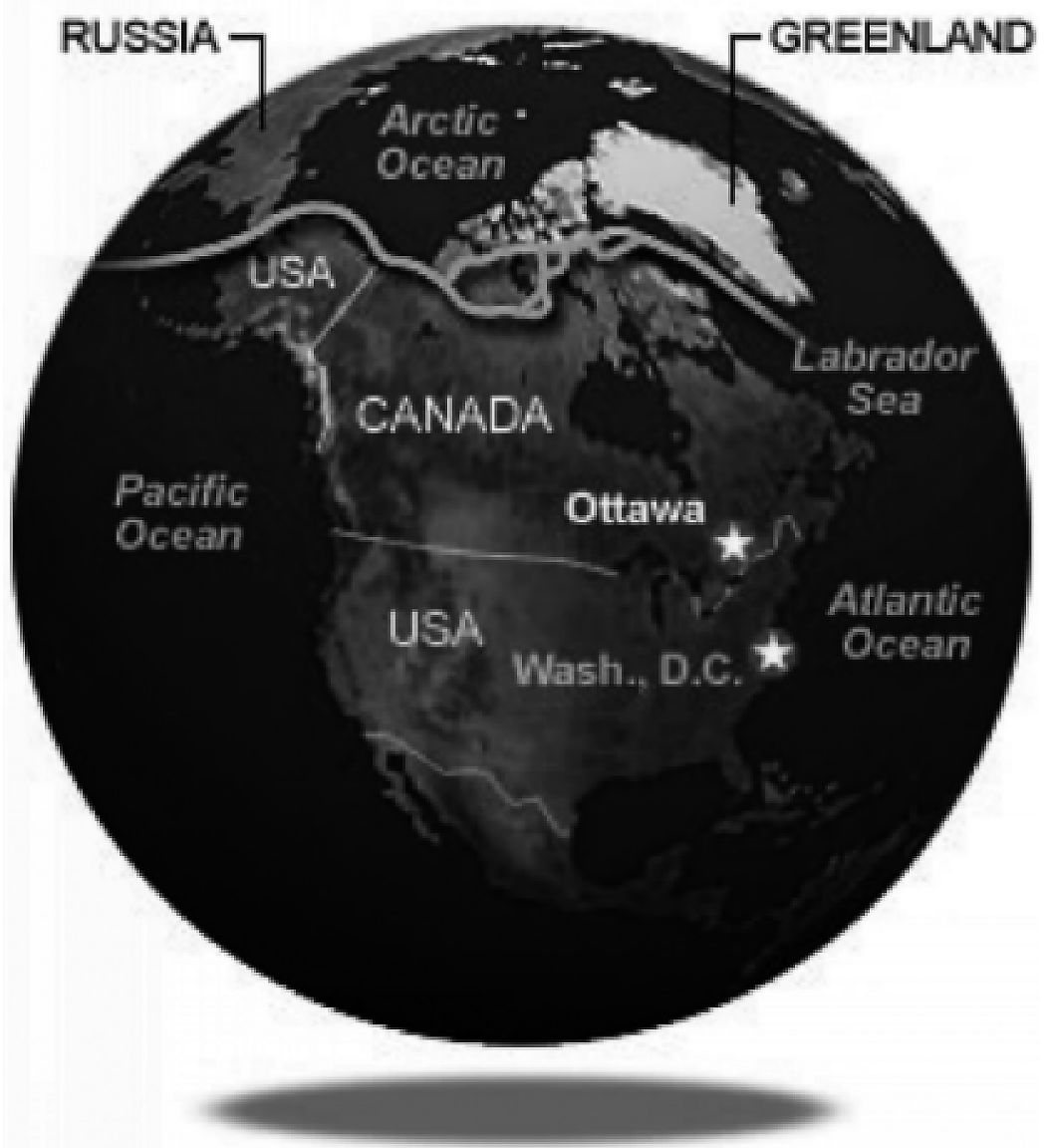

\section{By Ron Coddington, USA TODAY}

Mapa 5. Lokalizacja Przejścia Północno-Zachodniego

Źródło: R. Dube, As ice melts, debate over Northwest Passage heats, http://www.usatoday.com/news/world/ 2006-04-03-nwpassage-debate_x.htm (5.08.2009). 
Jeszcze większa korzyść z możliwości korzystania z Przejścia płynęłaby dla supertankowców, które zmuszone są do opływania Ameryki Południowej z powodu swoich gabarytów, uniemożliwiających im korzystanie z Kanału Panamskiego (Sevunts). Na kwestię tonażu i porównanie pod tym względem zwraca także uwagę Rob Huebert w swoim artykule dostępnym na stronie Canadian Defence \& Foreign Affairs Institute, podkreślając, że przepływ wspomnianego poniżej supertankowca Manhattan udowodniła, że z przejścia mogą korzystać nawet statki o masie 155000 ton, podczas gdy limit Kanału Panamskiego to 70000 ton (Huebert, Northern: 3-4).

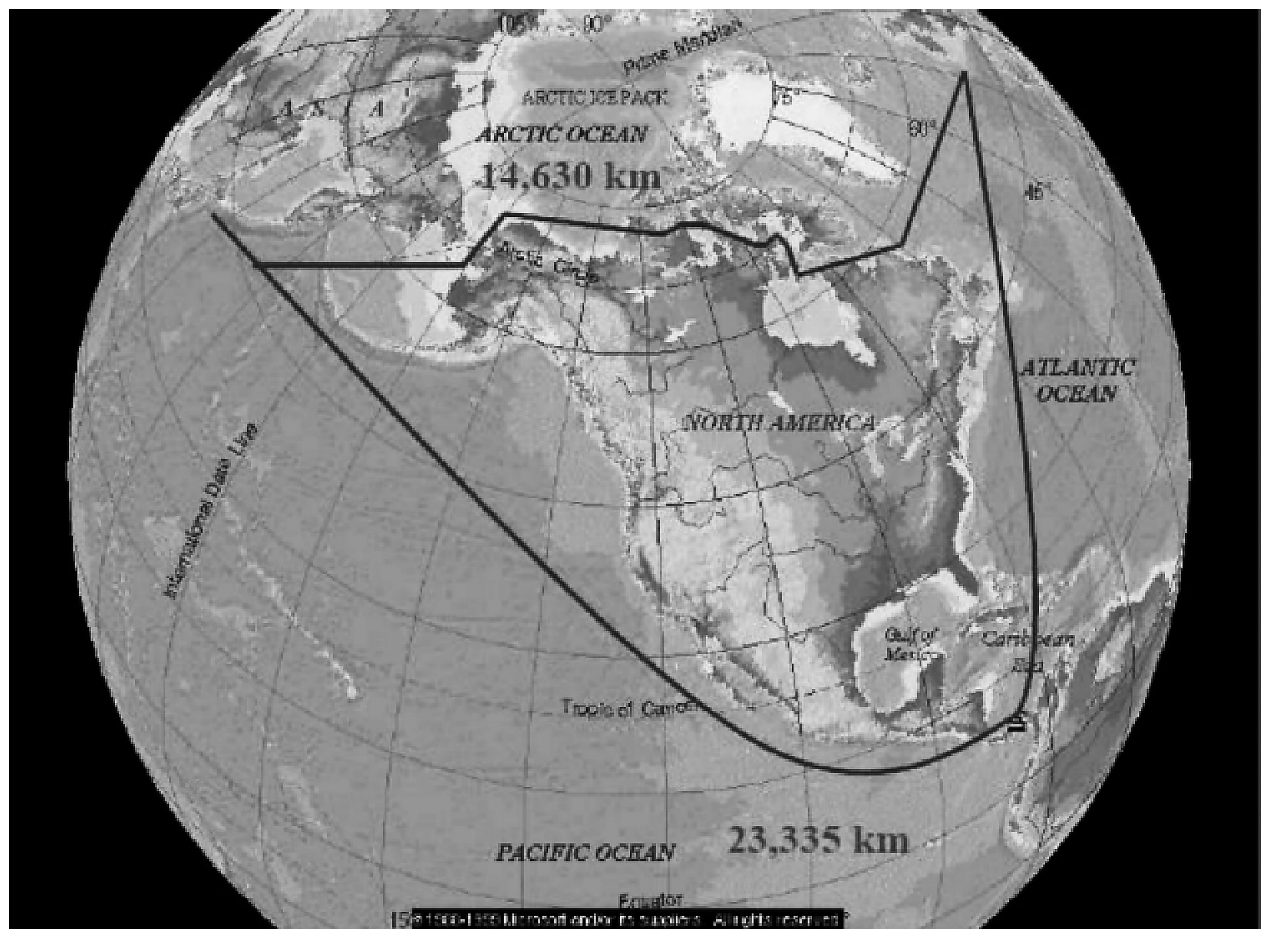

Mapa 6. Porównanie długości trasy morskiej prowadzącej z Europy do Azji przy wykorzystaniu Przejścia Północno-Zachodniego oraz Kanału Panamskiego

Źródło: R. Huebert, Climate Change and Geopolitics in the Arctic: Canada - US Relations, http://canada.berkeley.edu/icemelting/huebert.pdf (6.08.2009), s. 25.

Warunkiem wykorzystywania przejścia jest stopienie się pokrywy lodowej na tyle, by możliwe było korzystanie $\mathrm{z}$ niego przez statki nieposiadające odpowiednich wzmocnień konstrukcyjnych. Jednakże problemem nie jest jedynie pokrywa lodowa, ale i status Przejścia i w tej właśnie kwestii uwidaczniają się różnice pomiędzy Kanadą a Stanami Zjednoczonymi. Od kiedy w roku 1969 amerykański supertankowiec Manhattan - w towarzystwie kanadyjskiego lodołamacza - oraz następnie jedynie kilka innych statków przepłynęło przez Przejście, Stany Zjednoczone uznały je za trasę międzynarodową (Dube, 2006), podczas gdy ówczesny premier Kanady Elliot Trudeau oświadczył, że ,wody w ramach Archipelagu Arktycznego są wodami wewnętrznymi, nad którymi Kanada sprawuje suwerenną władzę" (Loyer, 2011: 4-5), przy czym również 
to roszczenie Kanady znajduje uzasadnienie we wspomnianej wcześniej teorii sektorów arktycznych (Symonides, 2008: 33-34). Rok później parlament Kanady przyjął wspomniany już wcześniej Arctic Waters Pollution Prevention Act, którego celem było zapewnienie jurysdykcji kanadyjskiej nad 100 milami wód od linii brzegowej dla ochrony przed zanieczyszczeniami (Zorzetto, 2006) ${ }^{5}$. Stany Zjednoczone zaprotestowały, podważając legalność tej ustawy z powodu „bezprawnej ingerencji w prawo i wolność żeglugi” (Roach, Smith, 2012: 319).

W roku 1973 władze Kanady ogłosiły, że przejście stanowi jej wewnętrzną trasę wodna, co spotkało się ze sprzeciwem USA (Dube, 2006). W 1985 r. nastapiła swoista próba sił pomiędzy USA a Kanada. Stany Zjednoczone poinformowały władze kanadyjskie o planowanym przepływie lodołamacza Polar Sea dodając przy tym, że będzie to sprawdzenie ,praw i wolności nawigacji nie wymagających wcześniejszego powiadamiania", zapraszając jednocześnie kanadyjskich przedstawicieli do uczestnictwa w przepływie. Władze Kanady doceniły zaproszenie przypominając jednakże, że Przejście Północno-Zachodnie stanowi wewnętrzne wody tego państwa. W odpowiedzi USA stwierdziły, że nie podzielają tego poglądu oraz że „nie poszukiwały zgody rządu Kanady na przepływ”. Rząd Kanady wyraził „głęboki żal” z tego powodu przypominając jednocześnie, że omawiane wody nie podlegają jakimkolwiek międzynarodowym reżimom. Ostatecznie do przepływu Polar Sea doszło, zaś przedstawiciele Kanady wzięli w nim udział (Roach, Smith, 2012: 320-324). Warte odnotowania jest, że w tym samym roku protest wobec stanowiska Kanady wystosowała także występująca w imieniu Wspólnoty Europejskiej Wielka Brytania, jednakże jak zaznacza to Rob Huebert, Wspólnota podejmowała ograniczone działania w tym zakresie, preferując sytuację, w której to działania byłyby podejmowane przede wszystkim przez USA (Huebert, 2011: 389). Należy jednak podkreślić, że stanowisko Unii Europejskiej, a tym samym większości państw NATO, pozostało w tej kwestii niezmienne.

W 1988 roku premier Kanady Brian Mulroney oraz prezydent USA Ronald Reagan podpisali Arctic Cooperation Agreement ${ }^{6}$, na mocy którego amerykańska straż przybrzeżna może wykorzystywać przejście po powiadomieniu Kanady, która z kolei nie może nie udzielić zgody (Sevunts). Pierwszą próbą dla porozumienia była wystosowana przez Stany Zjednoczone prośba o zgodę na przepływ lodołamacza straży przybrzeżnej Polar Star w celu przeprowadzenia badań naukowych. Kanada takiej zgody udzieliła przypominając jednocześnie Stanom Zjednoczonym o odpowiedzialności za wszelkie potencjalne szkody dla środowiska powstałe w wyniku przepływu, zgodnie z Arctic Waters Pollution Prevention Act (Roach, Smith, 2012: 326), następcy oprotestowanej wcześniej przez USA ustawy kanadyjskiej, w nowej jej wersji z roku $1985^{7}$. Wspomniane ustalenie znalazło swoje potwierdzenie w późniejszej polityce arktycznej

5 Obawy Kanady co do zanieczyszczenia Przejścia Północno-Zachodniego nie są bezpodstawne. Zdaniem Pete Erwina współpracującego z kanadyjskim oddziałem World Wildlife Fund otwarcie Przejścia spowoduje „odpalenie ekologicznej bomby zegarowej”, ponieważ niemożliwe jest oczyszczenie z plam ropy lodowatych wód. Szerzej: Canada flexes...

${ }^{6}$ Pełna treść porozumienia w: J. A. Roach, R. W. Smith (2012), Excessive Maritime Claims: Third Edition, Leiden, s. 324-325.

7 Obecna, ujednolicona treść ustawy: Consolidation. Arctic Waters Pollution Prevention Act, R. S. C., 1985, c. A-12, http://laws-lois.justice.gc.ca/PDF/A-12.pdf. 
George'a W. Busha, o czym patrząc z perspektywy Kanady cytowany w artykule CBC mówił Michael Byers: „musimy być proszeni o pozwolenie i musimy dawać pozwolenie" (Work). Pod koniec lat 80. XX wieku władze Kanady zwróciły się do Stanów Zjednoczonych z pytaniem czy uznałyby prawo Kanady do Przejścia, jeżeli miałyby zagwarantowany pełny dostęp dla marynarki wojennej w czasie kryzysu, jednakże otrzymały odpowiedź odmowną (Roach, Smith, 2012: 325). W kontekście roszczenia Kanady do Przejścia Północno-Zachodniego i jego uznawania należy podkreślić, że USA - w przeciwieństwie do innych państw - często celowo nie informowały Kanady o planowanych przepływach swoich jednostek, w tym także przykładowo okrętu podwodnego marynarki wojennej w 1995 roku (Randall, Thompson, 2010: 323). Nie był to zresztą jedyny przykład działań Stanów Zjednoczonych wycelowanych w roszczenie Kanady. W roku 1993 kanadyjska straż przybrzeżna zaprosiła inne państwa arktyczne do stworzenia zestawu zasad i standardów dotyczących działań jednostek morskich na wodach Przejścia. Jak pisze o tym Rob Huebert, Departament Stanu Stanów Zjednoczonych „,próbował wykoleić negocjacje z nie do końca jasnych powodów”, zaś kiedy osiagnięcie porozumienia wydawało się już być bliskie, Departament zgłosił swoje uwagi. Pomimo ich uwzględnienia USA w dalszym ciagu były niechętne poczynieniu dalszych postępów w prowadzonych negocjacjach (Huebert, 2011: 384-385).

Próbując przekonać Stany Zjednoczone do uznania Przejścia za jej wody terytorialne Kanada twierdzi, że posiadanie przez nią kontroli nad Przejściem będzie miało pozytywny wpływ na poziom bezpieczeństwa (Struck, 2006). W wydawanym w Toronto „Globe and Mail” znalazł się nawet artykuł, w którym zasugerowano George'owi W. Bushowi, że „kanadyjska kontrola prawna nad przepływem [w ramach przejścia, przyp. H.G.] stanowiłaby najlepszą ochronę przed zagranicznym awanturnictwem lub atakami terrorystycznymi" (Randall, Thompson, 2010: 324). Tezy te niespodziewanie znalazły poparcie w wypowiedzi byłego ambasadora USA w Kanadzie Paula Celuttiego, zdaniem którego w interesie bezpieczeństwa Stanów Zjednoczonych leży sprawowanie przez Kanadę kontroli nad Przejściem (Struck, 2006). Według P. Celuttiego w takim przypadku pełnia praw obowiązujących w Kanadzie mogłaby zostać zastosowana wobec potencjalnych terrorystów. Jednakże zdaniem Michaela Byersa Stany Zjednoczone nie miałyby powodów, by wierzyć, że Kanada będzie w stanie zainwestować wystarczającą ilość funduszy w odpowiednie zabezpieczenie tej trasy morskiej. W konsekwencji połączone kanadyjska jurysdykcja oraz niedoinwestowanie dałyby efekt gorszy niż uznanie przejścia za trasę międzynarodową.

Nawiązując do uwag z części artykułu poświęconej sporowi o Wyspę Hans należy podkreślić, że o ile po wygranych wyborach premier Stephen Harper zapowiedział zapewnienie kontroli na przejściem obiecując zainwestowanie 5,3 miliarda dolarów kanadyjskich m.in. w trzy uzbrojone lodołamacze, głębokowodny port w pobliżu Iqaluit (stolicy Nunavut) przy wschodnim wejściu (Randall, Thompson, 2010: 324), budowę bazy wojskowej w samym Nunavut oraz zwiększenie liczby patroli (ibidem: 324), to rząd kanadyjski przez ponad pół roku nie doprowadził do sfinansowania żadnego z tych projektów (Struck, 2006). Kanadyjskie plany spotkały się ze zdecydowanym sprzeciwem ze strony władz Stanów Zjednoczonych i Danii, ale także i Rosji. Obecnie planowane jest zwiększenie kanadyjskiej wojennej i patrolowej floty arktycznej w ramach National Shipbuilding Procurement Strategy. Zakłada się docelową budowę 
przez Irving Shipyards w Halifaxie nawet do 23 statków i okrętów za łączną kwotę 29,3 mld dolarów amerykańskich (New ships).

Kolejną słabością Kanady jest niedobór helikopterów ratowniczych w omawianym regionie, łodzi podwodnej zdolnej przemieszczać się pod pokrywą lodową, zaś posiadane wysłużone lodołamacze „wagi średniej” opuszczają Arktykę na zimę (Struck, 2006). W sierpniu 2007 r. pojawiły się kolejne obietnice: port morski na Wyspie Baffina oraz nowe wojskowe centrum szkoleniowe w Zatoce Resolute, zostały one dodane do wcześniejszej obietnicy wyprodukowania przynajmniej sześciu arktycznych statków patrolowych (The Northwest) ${ }^{8}$. Dla porównania w marcu 2009 r. pojawiły się informacje o planie wysłania przez USA dwóch nuklearnych łodzi podwodnych na ćwiczenia wojskowe w pobliżu Alaski przez Przejście Północno-Zachodnie (Work), Dania jest zaś w posiadaniu czterech wzmocnionych na potrzeby poruszania się po wodach arktycznych fregat. Braki w wyposażeniu Kanady nie dotyczą jedynie możliwości potencjalnego interweniowania, ale nawet obserwacji Przejścia, ponieważ jedyną ale ograniczoną możliwość dawał satelita RADARSAT-1 (Sevunts). Pozytywnym sygnałem było dopiero wystrzelenie w $2007 \mathrm{r}$. satelity RADARSAT-2.

W przypadku postępowania globalnego ocieplenia sprawa kontroli i statusu przejścia będzie wymagała rozwiązania. Od roku 2000 przez krótki okres w trakcie lata przejście jest dostępne dla statków komercyjnych (Canada flexes); zgodnie z danymi Canadian Ice Service powierzchnia pokrywy lodowej na obszarze Archipelagu Arktycznego zmniejszyła się w latach 1969-2004 o 15\% w części wschodniej, w części zachodniej miejscami nawet o $36 \%$ (Sevunts). Zdjęcia satelitarne pokazują, że pokrywa lodowa na Oceanie Arktycznym zmniejszała się o około 3-4\% w każdej dekadzie, zaś według Johna Falkingama z Canadian Ice Service od roku 2000 tempo to wzrosło do $8 \%$. Powoduje to, że zdaniem Michaea Byersa przejście jest dostępne do celów komercyjnych (Dube, 2006). Sytuacja taka miała miejsce w 2007 r., kiedy Canadian Ice Service i amerykańskie National Ice Centre potwierdziły, że Przejście jest niemalże całkowicie wolne od lodu (The Northwest).

W tym kontekście w pełni uzasadnione jest twierdzenie Alicii Zorzetto z The Inventory of Conflict \& Environment, zgodnie z którym bez postępującego globalnego ocieplenia spór o status przejścia $\mathrm{w}$ obecnej formie nie zaistniałby (Zorzetto, 2006). Administracja Baracka Obamy zobowiązała się do ratyfikacji Konwencji o Prawie Morza podtrzymując tym samym deklaracje administracji George'a W. Busha (Alberts), Kanada zaś przy nieuregulowanym statusie Przejścia posiada bardzo ograniczone możliwości podjęcia działań w przypadku, gdyby USA zdecydowały się na rzucenie wyzwania kanadyjskim roszczeniom poprzez wysłanie $\mathrm{w}$ te regiony wzmocnionego supertankowca, o czym mówił Franklyn Griffiths, emerytowany profesor nauk politycznych Uniwersytetu Toronto. Powstaje bowiem pytanie co zrobić z takim statkiem? W przypadku dalszego topnienia lodowców i regularnego otwierania się Przejścia możliwe stanie się spełnienie funkcjonalnego wymogu, by uznać dane przejście za tra-

8 Więcej na temat zdolności działania Kanady na obszarze Arktyki oraz niedoborach sprzętowych i infrastrukturalnych tego państwa - patrz R. Huebert, Climate Change and Canadian Sovereignty in the Northwest Passage, „Calgary Papers in Military and Strategic Studies”, nr 4/2011, s. 392-395. 
sę międzynarodową: występowania w nim międzynarodowego ruchu morskiego (Côté, Dufresne: 3). W takiej sytuacji władzom Kanady znacznie trudniej byłoby uzasadniać i dochodzić praw do przejścia.

Omówione w artykule spory terytorialne pokazują, że w przypadku potencjalnego zysku w postaci wód terytorialnych, dostępu do tras morskich, a przede wszystkim złóż surowców możliwe jest zaistnienie sytuacji konfliktogennych nawet pomiędzy państwami tworzącymi tak silny sojusz jak NATO. Poszczególne państwa bowiem w naturalny sposób będą dążyły do zabezpieczenia swoich interesów. Przynależność do Sojuszu Północnoatlantyckiego wydaje się jedynie gwarantować, że istnienie tych sporów pozostanie na płaszczyźnie politycznej.

Nie bez znaczenia dla intensywności oraz częściowo zaistnienia tychże sporów jest stopień pogłębiania się zjawiska globalnego ocieplenia. Jeżeli bowiem powodowane nim topnienie lodowców arktycznych będzie postępować, coraz łatwiejszy będzie się stawał dostęp do omówionych tras morskich i surowców. Podobnie w przypadku odwrócenia trendu - stopniowego odbudowywania się arktycznej pokrywy lodowej koszt eksploatacji tras oraz złóż stanie się ponownie na tyle wysoki, że poniesienie kosztów niezbędnych inwestycji przestanie być opłacalne dla Kanady, Stanów Zjednoczonych i Danii. Niemniej jednak z opisanych w artykule powodów na obszar Arktyki wciąż zwrócone będą oczy polityków, a przede wszystkim przywódców państw zaangażowanych w opisane spory.

\section{Bibliografia}

Alberts S., Obama 'committed' to resolving Arctic disputes: Clinton, http://byers.typepad.com/arctic/2009/04/obama-committed-to-resolving-arctic-disputes-clinton.html (26.02.2014).

Baker J. S., Byers M. (2012), Crossed Lines: The Curious Case of the Beaufort Sea Maritime Boundary Dispute, „Ocean Development \& International Law”, No. 43.

Baker J., Byers M., The Beaufort Sea Boundary Dispute: Identifying ad Assessing Options. A discussion paper prepared by James Baker \& Michael Byers, February 25, 2010, http://byers.typepad.com/files/baker-byers-discussion-paper-25-feb-2010.pdf (30.09.2014).

Beaufort Sea, http://www.absoluteastronomy.com/topics/Beaufort_Sea (6.08.2009).

Boswell R., Arctic mapping project exposes simmering dispute, http://www2.canada.com/windsorstar/news/story.html?id=0cfaa371-a3a8-4763-bf9f-3df00e0982b3 (26.02.2014).

Boswell R. (2009), Canada protests U.S. Arctic fishing ban, http://www.webcitation.org/query?url= http\%3A\%2F\%2Fwww.canada.com\%2FCanada\%2Bprotests\%2BArctic\%2Bfishing\%2F 1962264\%2Fstory.html\&date=2009-09-15 (25.02.2014).

Boswell R., Hans Island was ours first, Greenland says, http://byers.typepad.com/arctic/2008/12/ hans-island-was-ours-first-greenland-says.html (22.02.2014).

Bronskill J., Hans Island deal struck with Danes, http://byers.typepad.com/arctic/2008/11/hans-island-deal-struck-with-danes.html (22.02.2014).

Byers M. (2013), International Law and the Arctic, Cambridge. 
Byers M., Sovereignty will solve the Northwest Passage dispute, http://www.pugwashgroup.ca/ events/documents/2007/2007.08.11-Byers_article.pdf (25.02.2014).

Byers M., Stephen Harper, the Austin Powers of the Arctic, http://www.thestar.com/opinion/commentary/2013/09/01/stephen_harper_the_austin_powers_of_the_arctic.html (24.02.2014).

Canada and the Arctic: The Issue of Northern Sovereignty, http://www.wilsoncenter.org/event/canada-and-the-arctic-the-issue-northern-sovereignty (24.02.2014).

Canada flexes its muscles in scramble for the Arctic, http://www.guardian.co.uk/environment/2007/ jul/11/climatechange.climatechange (25.02.2014).

Canada, Denmark dispute ownership of tiny Arctic island, http://www.cbc.ca/news/canada/canada-denmark-dispute-ownership-of-tiny-arctic-island-1.565276 (23.02.2014).

Collins, Jr. E., Rogoff M. A. (1986), The Gulf of Maine Case and the Future of Ocean Boundary Delimitation, „Maine Law Review”, Vol. 38, No. 1.

Consolidation. Arctic Waters Pollution Prevention Act, R. S. C., 1985, c. A-12, http://www.laws-lois.justice.gc.ca/PDF/A-12.pdf (26.02.2014).

Côté F., Dufresne R., The Arctic: Canada's legal claims, „Infoseries”, PRB 08-05E, 24/10/2008, http://www.parl.gc.ca/content/lop/researchpublications/prb0805-e.pdf (25.02.2014).

DeMille D., Denmark' Goes Viking' in Canada's Arctic Islands, http://www.casr.ca/id-arcticviking1.htm (22.02.2014).

Denmark calls for talks on Arctic island dispute, http://archive.is/Jvkdo (23.02.2014).

Dube R. (2006), As ice melts, debate over Northwest Passage heats, „USA Today”, http://www.usatoday.com/news/world/2006-04-03-nwpassage-debate_x.htm (25.02.2014).

Fogarassy T., The Alaska Boundary Dispute: History and International Law, http://www.cwilson.com/pubs/energy/alaska.pdf (7.08.2009).

Guo R. (2006), Territorial Disputes and Resource Management: A Global Handbook, Nowy Jork. Harper K., Hans history, http://www.canadiangeographic.ca/hansIsland/background.asp (22.02.2014).

Huebert R. (2011), Climate Change and Canadian Sovereignty in the Northwest Passage, „Calgary Papers in Military and Strategic Studies", No. 4.

Huebert R., Northern Interests and Canadian Foreign Policy, http://www.cdfai.org/PDF/Northern\%20Interests\%20and\%20Canadian\%20Foreign\%20Policy.pdf (27.02.2014).

Huebert R. (2002), Return of the Vikings, „Globe and Mail”, http://www.byers.typepad.com/arctic/2008/11/return-of-the-vikings.html (25.02.2014).

Joint Statement, w01.international.gc.ca/minpub/Publication.aspx?isRedirect=True\&publication_id= $383048 \&$ Language $=\mathrm{E}(5.08 .2009)$.

Kristensen P. E. D., Hans Island: Denmark Responds, Letter to the Editor, http://byers.typepad.com/ arctic/2009/02/hans-island-denmark-responds.html (22.02.2014).

Konwencja Narodów Zjednoczonych o prawie morza, sporzqdzona w Montego Bay dnia 10 grudnia 1982 r., Dz. U. 2002, Nr 59, poz. 543.

Loyer J. (2011), Melting Proof: Reassessing Canada's Legal Claims Over the Northwest Passage, „Brussels Journal of International Studies”, Vol. 8.

New ships for navy, coast guard, http://www.cbc.ca/news2/interactives/shipbuilding/ (27.02.2014).

Randall S. J., Thompson J. H. (2010), Canada and the United States: Ambivalent Allies, Athens.

Roach J. A., Smith R. W. (2012), Excessive Maritime Claims: Third Edition, Leiden.

Satelite imagery moves Hans Island boundary: report, http://www.cbc.ca/news/technology/satellite-imagery-moves-hans-island-boundary-report-1.684285 (21.02.2014).

Schofield C., Townsend-Gault I., Of Parallels and Meridians: Implications of Barents Sea Dispute Resolution for the Beaufort Sea, http://www.zeitschrift.co.uk/indexv7n1.html (28.02.2014). 
Secretary of Commerce approves fisheries plan for Arctic, http://www.noaanews.noaa.gov/stories2009/20090820_arctic.html (25.02.2014).

Sevunts L., As Arctic Ice Melts, Canada Reasserts Sovereignty Over Its 'Northwest Passage', $\mathrm{http}: / / w w w . w o r l d a n d i . c o m / s u b s c r i b e r s / f e a t u r e+d e t a i l . a s p ? n u m=24655$ (5.08.2009).

Struck D. (2006), Dispute Over NW Passage Revived, „The Washington Post”, http://www.washingtonpost.com/wp-dyn/content/article/2006/11/05/AR2006110500286.html (26.02.2014).

Symonides J. (2008), Status prawny i roszczenia do Arktyki oraz Bieguna Pólnocnego, „Państwo i Prawo", nr 1.

The Hans of Time, http://www.canadiangeographic.ca/hansIsland/time.asp (22.02.2014).

The List: The World's Forgotten Teritorial Disputes, Canada and Denmark, www.foreignpolicy.com/story/cms.php?story_id=3534 (21.02.2014).

The Northwest Passage: in dispute, and navigable, http://www.canada.com/montrealgazette/ news/story.html?id=8df15e06-e40d-42da-b42e-61c0d0713260 (26.02.2014).

US to ban fishing on Beaufort Sea, http://www.worldfishingtoday.com/news/default.asp?nyId=3742 (25.02.2014).

Wallace J., Diplomacy for Hans Island dispute, http://www.canadiangeographic.ca/hansIsland/diplomacy.asp (22.02.2014).

Weber B., Another U.S.-Canada Arctic mapping trip won't resolve boundary dispute, http://www.breitbart.com/article.php?id=cp_h4nj00gse4\&show_article=1 (24.02.2014).

Work together on Arctic sovereignty disputes, expert urges Canada, U.S., http://www.cbc.ca/canada/north/work-together-on-arctic-sovereignty-disputes-expert-urges-canada-u-s-1.799315 (25.02.2014).

Zorzetto A. (2006), Canadian Sovereignty at the Northwest Passage, „ICE Case Studies”, No. 185.

\title{
STRESZCZENIE
}

W niniejszym artykule przeanalizowane zostały trzy przypadki sporów terytorialnych pomiędzy państwami członkowskimi NATO: spór pomiędzy Kanadą i Danią o znajdującą się w Kanale Kennedy'ego Wyspę Hans, spór pomiędzy Stanami Zjednoczonymi i Kanadą o część Morza Beauforta oraz kwestia Przejścia Północnozachodniego, które uznawane jest przez Kanadę za wewnętrzne wody terytorialne, czemu sprzeciwiają się Stany Zjednoczone oraz europejskie państwa członkowskie NATO. Spory te mają miejsce z następujących powodów: dostępu do nowych tras morskich oraz do bogatych złóż ropy i gazu. W artykule przeanalizowane zostały uwarunkowania zaistnienia tych sporów oraz przedstawione zostały najważniejsze wydarzenia $\mathrm{z}$ ich przebiegu. Została także podjęta próba określenia dotychczasowego oraz potencjalnego przyszłego wpływu globalnego ocieplenia na kształt tych sporów.

\section{TERRITORIAL DISPUTES OF NATO MEMBER STATES IN THE ARCTIC. DETERMINANTS, IMPORTANCE AND THE IMPACT OF GLOBAL WARMING}

\begin{abstract}
In the article the cases of three territorial disputes between the NATO member states were analyzed, these are: the dispute between Canada and Denmark over the Hans Island in the Kennedy Channel, the dispute between United States and Canada over the part of the Beaufort Sea and the
\end{abstract}


case of the Northwest Passage, which is considered by Canada as its internal waters while this position is rejected by United States and the other European NATO members. These disputes are in place for the following reasons: access to the potentially newly accessable sea routes and access to rich oil and gas fields. In the article the determinants of these disputes were analyzed as well as most important events that took place during the disputes. An attempt was also made to determine what is and what can be the future impact of global warming on the shape of these disputes. 